Izvorni članak UDK: 123(045)

doi: $\underline{10.21464 / \mathrm{fi4} 1103}$

Primljeno 2. 5. 2020.

\title{
Igor Mikecin
}

Sveučilište u Zagrebu, Filozofski fakultet, Ivana Lučića 3, HR-10000 Zagreb

imikecin@ffzg.hr

\section{Filozofija kao znanost slobode}

\begin{abstract}
Sažetak
U skladu s trodiobom Hegelova sistema na logiku, filozofiju prirode i filozofiju duha, raščlanjuje se i Hegelovo poimanje slobode. Sloboda je u logici sloboda samoga pojma, koji se u sebi oslobađa od svojih određenja u logici bitka i biti za određenja koja zadobiva u logici pojma. Pojam dospijeva do svoje slobode u apsolutnoj ideji, koja nije drugo nego ideja slobode. Na logičkom pojmu slobode počiva sloboda prikazana u filozofiji duha na svim stupnjevima njegova razvoja, dočim se u filozofiji prirode priroda razumije kao negacija slobode i nužno posredovanje ideje slobode u daljnjem hodu njezina ozbiljenja. U filozofiji duha otkriva se da je sloboda bit duha. Sebesvijest duha najprije se budi u vidu subjektivnoga duha, koji se oslobađa iz prirode. Daljnje ozbiljenje duha zbiva se kroz objektivni duh, koji se objektivira u apstraktnome pravu, moralnosti i ćudorednosti. U svjetskoj povijesti, koja je završno određenje objektivnoga duha, duh se ozbiljuje kao napredak u svijesti slobode. U oblasti objektivnoga duha sloboda se shvaća kao sloboda volje. Volja pritom nije supstrat slobode, a sloboda nije tek svojstvo volje, nego je supstancija ili bit volje. U skladu $s$ raščlambom objektivnoga duha na apstraktno pravo, moralnost $i$ ćudorednost, početna apstraktna sloboda razvija se $k$ sve konkretnijoj slobodi. Apstraktno pravo, moralnost $i$ ćudorednost stupnjevi su jedinstvenoga razvoja i ozbiljenja slobode. Dok subjektivnomu duhu pripada subjektivna sloboda kao sloboda izbora neposredno danih sadržaja i svrha (neposredna ili prirodna volja), objektivnomu duhu pripada formalna sloboda osobne volje (pravo), zatim formalna sloboda samozakonodavne subjektivne volje (moralnost) i napokon supstancijalna sloboda supstancijalne volje (ćudorednost). Ali na kraju ćudorednosti preostaje još nesloboda koju objektivni duh kao takav ne može nadići. Sloboda je na stupnju objektivnoga duha još uvijek ograničena jer se pojavljuje kao sloboda volje. Sloboda kao bit duha dospijeva do svojega osvještenja istom kada se ono apsolutno osvijesti kao apsolutni duh u umjetnosti, religiji i filozofiji. Sva ta tri lika apsolutnoga duha na svoj način nadilaze slobodu volje, ali je među njima filozofija najslobodniji lik duha. U filozofiji kao apsolutnoj znanosti doseže se najviši lik sebesvijesti duha, a to znači potpuno osvještenje slobode kao njegove biti. Pritom svaki stupanj ozbiljenja slobode od subjektivnoga preko objektivnoga do apsolutnoga duha ima svoje nezaobilazno mjesto, a naposljetku su svi stupnjevi objedinjeni u cjelinu nužnih momenata sistema. Kroz filozofiju kao apsolutnu znanost duh se potpuno oslobađa za slobodu kao svoju bit. Duh je određen kao vraćanje k samomu sebi iz svojega drugoga, tako da duh naposljetku ukida svaku izvanjskost i prisvaja ju u svoju unutrašnjost, otkriva da ono drugo od njega nije odvojeno od njega nego je njegovo biti drugim. Prije svake slobode volje, bilo slobode izbora, moralne slobode ili ćudoredne slobode, sloboda je bit duha i to kao sebesamoodređenje, koje se ne podvrgava nikakvomu izvanjskomu određenju: biti pri sebi u drugome samoga sebe, tj. sebeodnos kroz odnos $s$ drugim kao vlastitim drugim. Filozofija je kao znanost onog apsolutnog ujedno znanost slobode jer je sloboda sama bit onoga apsolutnog. Po slobodi se ono apsolutno kao apsolutna ideja iz svojega biti po sebi slobodno prevraća u prirodu kao svoje biti drugim i vraća se $k$ samomu sebi u duhu te se u svojoj istini otkriva kao apsolutni duh. Apsolutna ideja nije drugo nego po sebi jesući duh, a ono apsolutno je po svojem najvišem određenju apsolutno sebesvjesni duh. Apsolutna znanost kao najviši lik apsolutnoga duha apsolutna je sebesvijest onoga apsolutnog samog. To da je filozofija znanost slobode ne znači da je sloboda samo predmet filozofije nego i da se sama sloboda kroz filozofiju otkriva i ozbiljuje u svojoj istini. Istina slobode jest to da je sloboda bit onoga apsolutnog, a ono apsolutno oslobođeno za svoju istinu jest apsolutni duh.
\end{abstract}

\section{Ključne riječi}

sloboda, ono apsolutno, apsolutna ideja, apsolutni duh, objektivni duh, sloboda volje, filozofija kao apsolutna znanost 
Odloživši svoje ime ljubavi prema znanju, filozofija se u Hegela uzdiže do znanosti i u svojem savršenom liku, naime ukoliko je znanost istine onog apsolutnog, postaje apsolutnom znanošću. Znanstvenost filozofije sastoji se $\mathrm{u}$ tome da je ona sistem, a sistem podrazumijeva da se jedna jedinstvena znanost umnaža u momente sistema i stoga je sistem filozofijskih znanosti. Kao apsolutna znanost i sistem filozofija je u Hegela znanost slobode (Enz $1 \S$ $5 \mathrm{Z}) .{ }^{1}$ Sloboda se u filozofiji očituje najprije u tome da za razliku od svih ostalih znanosti ona u svojoj znanstvenosti i sistematičnosti nije uvjetovana ničim izvan same sebe, nema svoj temelj u nečem drugom od sebe, o čemu bi ovisila. Kao što ne pretpostavlja svoj predmet, tako ne pretpostavlja ni svoju metodu. Apsolutna metoda nije drugo nego svijest o formi unutrašnjega sebekretanja svojega nepretpostavljivoga predmeta. Predmet i metoda filozofije tako su sjedinjeni da filozofija proizvodi svoj predmet kroz metodu koja je način kretanja onog apsolutnog samog. Nema dakle ničega danoga i pretpostavljenoga, od čega bi filozofija polazila, nego je ona nužno početak same sebe. Početak filozofije je neposredan jer kad bi bio posredan, to bi značilo da ima nečega početnijeg od njega što mu prethodi i u čemu se temelji, pa tada ne bi bio istinski početak. Istovremeno, filozofija kao sistem prikazuje se kao posredovanje pa se stoga ni njezin početak ne može postaviti i pretpostaviti kao nešto jednostavno neposredno. Stoga sistem filozofije ima kružno kretanje, u kojem se neposrednost i posredovanje ne mogu međusobno odvajati: neposrednost početka filozofije uvijek je već posredovana neposrednost, tj. takva neposrednost koja je određena ishodom u kojem se filozofija vraća u sebe i ponovno doseže svoj početak. ${ }^{2}$

Filozofija je sistem utoliko što je znanost slobode. Sistem je sustavljanje mnoštva momenata u nužnu cjelinu prema jednoj jedinstvenoj i sveobjedinjujućoj metodi. Budući da u sistemu svaki moment ima svoje mjesto i svoje određenje jedino na osnovi odnosa koji se uspostavlja sa svim drugim momentima i s cjelinom, sistem je sebeodnošenje onog apsolutnog kroz svoje vlastite momente - ideja, priroda i duh - bez ičega danoga i pretpostavljenoga što bi opstojalo neovisno o njemu. To odnošenje sebe spram samoga sebe dospijeva do svojega apsolutnog sebeosvještenja u filozofiji kao apsolutnoj znanosti. Momenti sistema filozofije nisu međusobno odvojeni poput posebnih znanosti, nego su razlučivi ali neodvojivi momenti cjeline. Pojedine filozofijske znanosti nisu zasebne i samostalne znanosti nego momenti koji se enciklopedijski šire u krugovima. ${ }^{3}$ Sistem filozofijskih znanosti jedinstvo je koje se ozbiljuje jedino kroz svoje uposebljenje u svojim momentima, a momenti imaju svoju posebnost jedino u međusobnom odnosu i odnosu s cjelinom.

Filozofija je znanost slobode jer ne pretpostavlja svoj predmet kao nešto dano, nego je on proizvod njezinog sebeodnošenja i sebeodređenja. Budući pak da filozofija bez sistema ne može biti znanstvena (Enz § 14 Z), sistem ne samo da ni na koji način ne protuslovi određenju filozofije kao znanosti slobode nego je njezin jedino mogući ustroj. Slobodna od svega vanjskoga i danoga, znanost slobode kroz svoju apsolutnu metodu iz same sebe razvija svoj sadržaj. Kao znanost slobode filozofija je nužno sistem slobode: sebeodnošenje u kojem je svaki moment u neodvojivom odnosu s drugim momentima sistema i s cjelinom samoga sistema i to tako da svaki moment ima svoje mjesto unutar sistema kao njegovo vlastito izvođenje pod vodstvom slobode. Znanost onog apsolutnog bitno je sistem jer ono može biti samo tako da sebe u sebi razvija i ujedno sudrži u jedinstvu kroz razlikovanje i određenje svojih nužnih momenata (Enz § 14). Apsolutna znanost sistem je slobode jer je bespretpostavna 
i sve njezine pretpostavke u svojoj pretpostavljenosti negiraju samu formu pretpostavljanja jer počivaju u slobodi kao onom bespretpostavnom samom.

Filozofija je kao znanost onog apsolutnog ujedno znanost slobode jer je sloboda sama bit onoga apsolutnog. Po slobodi se ono apsolutno kao apsolutna ideja iz svojega biti po sebi slobodno prevraća u prirodu kao svoje biti drugim i vraća se k samomu sebi u duhu te se u svojoj istini otkriva kao apsolutni duh. Apsolutna ideja nije drugo nego po sebi jesući duh, a ono apsolutno je po svojem najvišem određenju apsolutno sebesvjesni duh, koji dospijeva do apsolutnog jedinstva svojega biti po sebi i biti za sebe. ${ }^{4}$ Apsolutna znanost kao najviši lik apsolutnoga duha je apsolutna sebesvijest onoga apsolutnog samog.

To da je filozofija znanost slobode ne znači dakle da je sloboda samo predmet filozofije nego i da se sama sloboda kroz filozofiju otkriva i ozbiljuje u svojoj istini. Istina slobode jest to da je sloboda bit onoga apsolutnog, a ono apsolutno oslobođeno za svoju istinu jest apsolutni duh. Sloboda nije nešto dano, nego ono što duh kroz svoj razvoj osvaja i prisvaja kao svoju vlastitu bit. Duh je isprva samo po sebi slobodan i radi se o tome da postane slobodan po sebi i za sebe, da se zbiljski oslobodi kroz svoj razvoj. Različiti stupnjevi i oblici razvoja duha nisu drugo nego različiti stupnjevi njegovog oslobođenja ili ozbiljenja njegove slobode (Enz § 386). Oslobođenje je duha utoliko otklanjanje ograničenja u razvoju njegovog sebeosvještenja. Filozofija je, dospjevši do

U dodatku uz $\S 5$ prvoga izdanja Enciklopedije filozofijskih znanosti objavljene u Heidelbergu 1817. godine, određuje se filozofija kao »znanost slobode«. Mjesta iz heidelberške Enciklopedije navode se prema izdanju: Georg Wilhelm Friedrich Hegel, Gesammelte Werke, sv. 13, Enzyklopädie der philosophischen Wissenschaften im Grundrisse (1817), Wolfgang Bonsiepen, Klaus Grotsch (ur.), Meiner Verlag, Hamburg 2000., a označavaju oznakom Enz 1. Oznaka $Z$ stoji za dodatak uz paragraf (Zusatz).

2

U § 17 trećega izdanja Enciklopedije filozofijskih znanosti Hegel upozorava na to da filozofija ne počinje subjektivnom pretpostavkom jer nema neki poseban predmet, nego je mišljenje mišljenja: »Ali to je slobodni akt mišljenja da se mišljenje postavi na stajalište gdje jest za samoga sebe i time samo sebi daje $i$ rađa svoj predmet. Nadalje, stajalište koje se tako pojavljuje kao neposredno mora se unutar znanosti učiniti ishodom, i to njezinim posljednjim ishodom u kojem ona ponovno doseže svoj početak i vraća se u sebe. Na taj se način filozofija pokazuje kao krug koji se vraća natrag u sebe, koji nema početak u smislu drugih znanosti.« - Enz § 17. Mjesta iz berlinske Enciklopedije filozofijskih znanosti navode se prema izdanju: Georg Wilhelm Friedrich Hegel, Gesammelte Werke, sv. 20, Enzyklopädie der philosophischen Wissenschaften im Grundrisse (1830), Wolfgang
Bonsiepen, Hans-Christian Lucas (ur.), Meiner Verlag, Hamburg 1992., a označavaju se kraticom Enz i brojem paragrafa. Oznaka $Z$ stoji za dodatak uz paragraf (Zusatz).

\section{3}

U Uvodu trećega izdanja Enciklopedije filozofijskih znanosti, Hegel o tome kaže: »Svaki od dijelova filozofije je filozofijska cjelina, krug koji se zatvara u samome sebi, ali filozofijska je ideja u njem u posebnoj određenosti ili elementu. Pojedini krug, zato što je u sebi cjelovitost, također probija granicu svojega elementa i utemeljuje daljnju sferu; stoga se cjelina prikazuje kao krug krugova, od kojih je svaki nužan moment, tako da sistem svojih osobitih elemenata sačinjava cijelu ideju, koja se isto tako pojavljuje u svakom pojedinom.« - Enz $§ 15$.

4

U poglavlju »Pojam duha« na početku filozofije duha u trećem izdanju Enciklopedije filozofijskih znanosti, Hegel kaže: »Ono apsolutno je duh; to je najviša definicija onog apsolutnog. - Pronaći tu definiciju i pojmiti njezin smisao i sadržaj, to je bila, može se reći, apsolutna težnja svega obrazovanja i filozofije [...].«Zadaća je filozofije shvatiti ono apsolutno $» u$ njegovom vlastitom elementu, $\mathrm{u}$ pojmu« i tu zadaću filozofija ne može istinski izvršiti sve dok "pojam i sloboda nisu njezin predmet i njezina duša«. - Enz $§ 384$; usp. Enz $1 \S 180$. 
apsolutne znanosti, završni oblik oslobođenja duha, koji se nakon svih prethodnih stupnjeva duha zbiva u elementu čistoga ili spekulativnoga mišljenja. Sloboda je u Hegela ono prvotno i sveobjedinjujuće sistema filozofije, a u skladu s trodiobom sistema na logiku, filozofiju prirode i filozofiju duha, raščlanjuje se i poimanje slobode, koje se primjereno prikazuje jedino u cjelini sistema, a ne zasebno u nekom od njegovih dijelova. ${ }^{5}$ Sloboda je u logici prije svega sloboda samoga pojma, koji se u sebi oslobađa za svoju vlastitu istinu - apsolutnu ideju, koja stoga nije drugo nego ideja slobode. Pojam slobode pak javlja se u sklopu logičkoga prikaza sebeoslobođenja pojma upravo na prijelazu od ne-slobode pojma u logici bitka i biti k slobodi pojma u logici pojma, a zatim i dalje unutar logike subjektivnoga pojma. Od pojma slobode razlikuje se ideja slobode, a naposljetku apsolutna ideja, koja je istina onog apsolutnog samog u oblasti logike. Ideja je jedinstvo pojma i zbiljnosti, tj. pojam oslobođen do svoje subjektivnosti, a apsolutna ideja apsolutno je oslobođeni pojam ili ideja slobode. Bespretpostavnost filozofije u potpunosti izlazi na vidjelo u znanosti logike. Sloboda se u znanosti logike očituje u tome da ona nema nikakvoga pretpostavljenog sadržaja kao nečeg danog (Enz § 31). Svoj sadržaj logika zadobiva jedino kroz spekulativno mišljenje, koje iz samoga sebe proizvodi svoja određenja i time samo određuje samoga sebe (usp. Enz § 19 Z). Spekulativno je mišljenje bespretpostavno jer je slobodno od svih vanjskih postavaka na koje bi se oslanjalo ili od kojih bi polazilo. Početak logike u čistome biti neposredan je, ali to čime logika počinje ujedno je ono što je ishod filozofije duha, naime filozofija kao apsolutna znanost. Stoga početak logike nije samo neposredan nego je ujedno i posredovan dovršenjem filozofije u filozofiji apsolutnoga duha. To sebeodnošenje, tj. sebeodređivanje i sebepostavljanje, u kojem se zatvara krug sistema filozofije i koje nema ničega izvan samoga sebe što ne bi bilo njegov vlastiti proizvod, jest sloboda spekulativnoga mišljenja.

Na slobodi pojma kako je prikazana u logici zasniva se logički ustroj slobode kao biti duha na svim stupnjevima njegovog razvoja. Logika naime ne prikazuje samo slobodu pojma nego utemeljuje i zbiljsku slobodu, koja se izlaže u filozofiji duha. ${ }^{6}$ U filozofiji prirode sloboda se shvaća negativno. Budući da je sloboda moguća samo u oblasti onog duhovnog, priroda nije slobodna, nego je lišena slobode i podvrgnuta nužnosti. Ali ukoliko je priroda biti drugim onog apsolutnog samog, utoliko se ona također određuje polazeći od slobode, upravo kao negacija slobode koja nužno pripada samoj slobodi (Enz $\S 381 \mathrm{Z}$ ). U filozofiji duha napokon otkriva se da je sloboda bit duha. ${ }^{7}$ Duh je isprva slobodan po sebi, ali ne još i za sebe. Sebesvijest duha najprije se budi u vidu subjektivnoga duha, koji se oslobađa iz prirode. ${ }^{8}$ To međutim još nije istinski pojam subjekta, tj. sebesamoodređenje u drugome samoga sebe, koji se otkriva istom na kraju razvoja duha. Daljnje ozbiljenje duha zbiva se kroz objektivni duh, koji se objektivira u apstraktnome pravu, moralnosti i ćudorednosti. U svjetskoj povijesti, koja je završno određenje objektivnoga duha, duh se ozbiljuje kao napredak u svijesti slobode. Sloboda kao bit duha dospijeva do svojega osvještenja istom kada se ono apsolutno osvijesti kao apsolutni duh u umjetnosti, religiji i filozofiji. Umjetnost je takav lik apsolutnoga duha u kojem se ono apsolutno zre kao ljepota. Apsolutna religija ili religija apsolutne slobode (Enz $§ 163 \mathrm{Z}$ ) osvještava ga u predstavljajućem mišljenju boga. Filozofija nadilazi jednostranost umjetnosti i religije i ono apsolutno poima u njegovoj istini. U filozofiji kao apsolutnoj znanosti doseže se najviši lik sebesvijesti duha, tj. duh postaje po sebi i za sebe slobodan. Cjelokupna 
svjetska povijest izraz je povijesti duha koja se u svojoj istini otkriva poglavito u povijesti filozofije, a onda i u povijesti religije i povijesti umjetnosti. Stoga se i napredak u svijesti slobode zbiva na osnovi napredovanja po stupnjevima apsolutnoga duha kao i unutar svakoga stupnja. Pritom svaki stupanj ozbiljenja slobode od subjektivnoga preko objektivnoga do apsolutnoga duha ima svoje nezaobilazno mjesto, a naposljetku su svi stupnjevi objedinjeni u cjelinu nužnih momenata sistema.

Na početku logike u Enciklopediji filozofijskih znanosti u poglavlju »Predpojam«, Hegel upozorava na to da je logika osnova za sve ostale dijelove sistema, pa tako i za filozofiju duha: »Promatramo li slijedom dosadašenjega logiku kao sistem čistih mislenih određenja, tada se druge filozofijske znanosti nasuprot njoj - filozofija prirode i filozofija duha - pojavljuju takoreći kao primijenjena logika, jer ona je njihova oživljujuća duša. Interes ostalih znanosti tada je samo u tome da se spoznaju logičke forme u likovima prirode i duha, likovima koji su samo poseban način izražavanja formi čistoga mišljenja.« - Enz $§ 24 \mathrm{Z} 2$. U »Predgovoru« Osnovnih crta filozofije pra$v a$, Hegel napominje: »Narav spekulativnoga znanja opširno sam razvio u svojoj Znanosti logike; stoga je u ovom temeljnom nacrtu samo mjestimice dodano poneko objašnjenje o tijeku i metodi. Pri konkretnoj i u sebi tako mnogostrukoj kakvoći predmeta zanemareno je to da se u svim pojedinostima dokaže i istakne logički izvod. S obzirom na pretpostavljenu upoznatost sa znanstvenom metodom to se dijelom moglo smatrati suvišnim, a dijelom će samo od sebe biti uočljivo da cjelina kao i izgradnja njezinih članova počiva na logičkome duhu. Volio bih i da se ovaj spis shvaća i prosuđuje poglavito s te strane.«-GPR, »Predgovor«.

O položaju filozofije objektivnoga duha ili filozofije prava u cjelini sistema Hegel kaže: »Ovaj je udžbenik daljnje, posebice sistematičnije izvođenje istih temeljnih pojmova koji su o tom dijelu filozofije već sadržani u Enciklopediji filozofijskih znanosti (Heidelberg 1817).«-GPR, »Predgovor«. Filozofija prava je, naime, podrobna razradba onoga što je u trećem izdanju Enciklopedije filozofijskih znanosti iz 1830. godine obrađeno u $\S \S 483-$ 552 pod naslovom »Objektivni duh«. Prikaz slobode u cjelini sistema vidi npr. u: Éric Gaziaux, »La liberté selon Hegel«, Revue Théologique de Louvain 35 (2004) 3, str. 316-342, doi: https://doi.org/10.2143/rtl.35.3.2017449; Will Dudley, Hegel, Nietzsche and Philosophy. Thinking Freedom, Cambridge University Press, Cambridge 2002.
U Enciklopediji filozofijskih znanosti na početku filozofije duha u poglavlju Pojam duha Hegel tvrdi: »Bit duha je [...] sloboda.« - Enz $\S 382$. U dodatku istomu paragrafu: »Supstancija duha je sloboda.« (Enz $§ 382$ Z). Isto se određenje susreće u berlinskim Predavanjima o filozofiji duha: »Apsolutna osnova je ono na što se sve reducira, izvor. Ta apsolutna osnova ili supstancija duha njegova je sloboda, a određenje njegovog djelovanja, djelo duha, jest to da se on oslobodi.« - Georg Wilhelm Friedrich Hegel, Vorlesungen. Ausgewählte Nachschriften und Manuskripte, sv. 13, Vorlesungen über die Philosophie des Geistes. Berlin 1827/1828, Franz Hespe, Burkhard Tuschling (ur.), Meiner Verlag, Hamburg 1994., str. 7. Dalje: »Bit duha je sloboda.« - Ibid. str. 12. U uvodnim predavanjima o filozofiji svjetske povijesti iz 1830./1831. godine Hegel kaže: »Kao što je težina supstancija materije, tako je, moramo reći, sloboda supstancija, bit duha. [...] Filozofija nas međutim poučava da sva svojstva duha postoje samo po slobodi, da su sva samo sredstva za slobodu, da sva samo nju traže i proizvode; spoznaja je spekulativne filozofije to da je sloboda ono jedino istinito duha. [...] Duh je naprotiv upravo to: u sebi imati središte, jer on nema jedinstvo izvan sebe, nego ga je pronašao; on je u samome sebi i pri samome sebi. [...] Duh je biti pri samome sebi. Upravo je to sloboda, jer kada sam ovisan, odnosim se spram nečeg drugog koje nisam; ne mogu biti bez nečeg vanjskog; a slobodan sam kada sam pri samome sebi. To biti pri samome sebi duha jest sebesvijest, svijest samoga sebe.«-Georg Wilhelm Friedrich Hegel, Vorlesungen. Ausgewählte Nachschriften und Manuskripte, sv. 18, Vorlesungsmanuskripte II (1816-1831). Vorlesungen über die Philosophie der Weltgeschichte, Walter Jaeschke (ur.), Meiner Verlag, Hamburg 1995., str. 153 .

S obzirom na to da se duh oslobađa iz prirode kao negacije i izvanštenja ideje, oslobađanje duha negiranje je njegove vlastite vanjskosti, $\mathrm{u}$ kojem se on vraća u svoju nutrinu, a sloboda, koja je bit duha, nije drugo nego »apsolutna negativnost pojma kao identitet sa sobom « (Enz $§ 382$ ). 
Filozofija je onaj lik apsolutnoga duha u kojem duh dospijeva do potpunoga sebeosvještenja, a to znači do potpunoga osvještenja slobode kao svoje biti. Logika kao osnova filozofije prikazuje oslobođenje samoga pojma od najnerazvijenih kategorija sve do apsolutne ideje. Logička određenja u svojoj čistoći pripadaju poimajućemu ili spekulativnomu mišljenju, koje je oslobođeno od predstavljajućeg ili rezonirajućeg mišljenja, a također i od svih ostalih predstava, čuvstava i nagona, u kojima mišljenje robuje onomu što nije ono samo. Ali i sama je logika put oslobođenja od pojma koji jest samo po sebi (logika bitka) k pojmu koji jest za sebe (logika biti) do pojma koji jest po sebi i za sebe (logika pojma). Logika pojma je carstvo slobode (WL II, 15$)^{9}$ jer istom u njoj mišljenje postaje potpuno svjesno samoga sebe, odnosno postaje svjesno slobode kao svoje biti. U prijelazu iz logike biti k logici pojma obistinjuje se nužnost pojma, te on dolazi k samomu sebi otkrivajući sebe kao onoga koji samoga sebe postavlja i određuje. Pojam je tu u razlici prema supstanciji posredovano jedinstvo bitka i biti (refleksije). Iako je već i supstancija svojevrsni sebeodnos, ona još nije za sebe u svojem odnosu prema sebi i utoliko još nije slobodna. Pojam je slobodan ukoliko u svojem kretanju ostaje posve pri samome sebi i ujedno je kao u sebi razlučeno jedinstvo u drugome svojih momenata. Sloboda sebeodređivanja i ujedno sebeposredovanja u drugome pojma logička je osnova za svaki mogući poseban oblik slobode. Ona se održava ne samo unutar daljnjega logičkog razvoja pojma sve do apsolutne ideje, koja je potpuno oslobođenje pojma, nego i u daljnjem kretanju k onomu što iz apsolutne ideje slobodno proizlazi.

Prijelaz iz objektivne logike, koja obuhvaća logiku bitka i logiku biti, u subjektivnu logiku ili logiku pojma početak je dovršenja prijelaza od nužnosti k slobodi pojma. Na kraju logike biti, tj. u supstanciji kao završnom određenju biti, dosegnut je pojam nužnosti, u kojem su određenja bitka i biti (refleksije) dospjela u jedinstvo, što je osnova za prijelaz k logici pojma. Nužnost nije kategorija oprečna slobodi, nego pripada slobodi. Prevladana je nužnost stoga nužnost razvoja slobode, a sloboda je istina nužnosti (Enz § 158; WL II, 12).

$\mathrm{Na}$ ovome mjestu, jednako kao i na drugim mjestima u logici gdje se izričito pojavljuje pojam slobode, nije riječ o logičkom izvodu pojma slobode kao jedne među kategorijama. Budući da se sloboda ne svodi ni na pojam slobode ni na ideju slobode, ona nije vezana ni za jedno posebno mjesto u razvoju pojma i ni za jednu posebnu kategoriju, nego kao način odnošenja (WL II, 12) spekulativnog mišljenja u cjelini prožima sve kategorije na svim razinama logike. Unutrašnja sveza logike i slobode razvidna je tek iz cjeline logike, tj. na osnovi cjelokupnoga razvoja pojma samoga, a ne iz nekog njegovog posebnog stupnja. Što je sloboda u logičkome smislu, otkriva se na samome kraju logike, a to znači u apsolutnoj ideji, koja je ishod sebeoslobađanja pojma, tj. potpuno ili do svoje subjektivnosti oslobođeni pojam (WL II, 176). Shodno tomu ni apsolutna ideja kao sloboda pojma na kraju logike ne podliježe daljnjemu logičkomu izvodu.

Sloboda je dakle u logici pojmljena kao istina nužnosti. Nužnost se ponajprije otkriva na supstanciji, napose kao odnos supstancije i akcidencije, koji nije potpuno slobodan od izvanjskosti i slučajnosti. Nešto je neslobodno ili podvrgnuto nužnosti ako je u odnosu s nečim što mu je izvanjsko i ne čini ga onime što ono jest. Takav izvanjski odnos samo ga izvanjski određuje i sprječava ga u tome da samo sebe određuje i time da bude slobodno. Sloboda se međutim ne može postići tako da se ukine odnos kao takav. Sloboda je samo $\mathrm{u}$ tome da se izvanjski odnos, u kojem se ono što je u odnosu međusobno 
ograničava, prevlada pounutrenjem odnosa u jedinstvo. Sloboda se ne može ugroziti onim što je odredbeno za bit onoga što je u odnosu. Prijelaz iz nužnosti u slobodu ne sastoji se dakle u tome da se prekida odnos, nego u tome da se mijenja način odnošenja. Bivajući u odnosu s drugim ono slobodno ostaje pri samome sebi. Oslobođenje pojma ne sastoji se dakle samo u tome da pojam u drugome ima sebe kao drugo nego povrh toga da u drugome ima svoje vlastito biti. Njegovo drugo jest sebepostavljanje njega samoga. Sloboda pojma razvija se iz nužnosti tako što pojam slobodno pounutruje vanjskost svojih prethodno postavljenih određenja (Enz §158 Z).

Shvati li se ono što je u odnosu kao dio cjeline, cjelina je slobodna jer time što je u odnosu s dijelovima ona je ustvari u odnosu sa samom sobom. Svaki dio jest to što jest samo zahvaljujući tomu što je dio cjeline, koja je kao cjelina u svakome prisutna na način toga dijela. Dijelovi su nadalje slobodni jer im je na osnovi takvoga odnosa s cjelinom i njihov međusobni odnos unutrašnji, a ne vanjski. To znači da se dijelovi u odnosu s drugim dijelovima uspostavljaju $\mathrm{u}$ onome što jesu jer se odnoseći se $\mathrm{s}$ drugim dijelovima odnose spram cjeline u njima.

Pounutrenje vanjskoga ne obilježava samo prijelaz od nužnosti k slobodi nego i prijelaz od konačnoga $\mathrm{k}$ beskonačnomu. Ono konačno u odnosu je prema nečem drugom koje je njegova negacija i njime je ograničeno (Enz $§ 28 \mathrm{Z}$ ). Odnos između onih konačnih njihovo je međusobno ograničavanje. Budući da se ona međusobno određuju i ograničavaju po nužnosti, prijelaz od konačnosti k beskonačnosti može biti dvojak: ili takav da se prestanu ograničavati ili takav da ih granica čini onime što ona sama jesu. Sloboda međutim nije u prestanku ograničavanja uopće, što je samo negativna beskonačnost jer je samo negacija konačnoga kojom se konačnost ne ukida, nego u takvom ograničavanju u kojem granica ono ograničeno čini onim što ono samo jest. To je istinska beskonačnost, $\mathrm{u}$ kojoj je ono ograničeno moment cjeline koja samu sebe određuje. Ono istinski beskonačno sastoji se u dolaženju k samomu sebi i u ostajanju pri samome sebi u svojem drugom (Enz § 93-95). ${ }^{10}$

Prvi stupanj svojega oslobođenja unutar logike subjektivnoga pojma pojam doseže u nauku o sudu i zaključku. Sud (Urteil) se tu shvaća kao pra-dioba (Ur-teil) utoliko što on, u razlici prema zaključku, još nije potpuni nego samo izvanjski identitet subjekta i predikata, koji su na taj način poistovjećeni da ostaju dva međusobno neovisna i izvanjska dijela suda. U ustroju suda nalazi se nedostatak slobode, koji se promatra kroz odnos kategorija pojedinačnosti, posebnosti i općosti. Pojam, sud i zaključak razlikuju se prema različitim načinima na koji se ta tri momenta u njima međusobno odnose. Dok su u pojmu kao takvom oni neposredno sjedinjeni, u sudu su odvojeni tako da je subjekt

Mjesta iz Znanosti logike navode se prema izdanju: Georg Wilhelm Friedrich Hegel, Gesammelte Schriften, sv. 11, Wissenschaft der Logik. Erster Band. Die objektive Logik (1812/13), Friedrich Hogemann, Walter Jaeschke (ur.), Meiner Verlag, Hamburg 1978.; Georg Wilhelm Friedrich Hegel, Gesammelte Schriften, sv. 12, Wissenschaft der Logik. Zweiter Band. Die subjektive Logik (1816), Friedrich Hogemann, Walter Jaeschke (ur.), Meiner Verlag, Hamburg 1981., a označavaju se kraticom WL I, odnosno WL II, i brojem stranice.
10

U Enz $\S 95$ Hegel određuje istinsku beskonačnost: »Nešto je $u$ odnosu prema nečem drugom već i samo nešto drugo prema njemu; budući da je ono u što prelazi posve isto kao i ono koje prelazi - ni jedno od njih nema nikakvo daljnje određenje nego jedno te isto, naime to da su nešto drugo - time se nešto u svojem prelaženju u drugo sastaje samo sa samim sobom, i taj odnos prema samome sebi $\mathrm{u}$ prelaženju i u drugome jest istinska beskonačnost.« 
suda moment pojedinačnosti, a predikat je moment općosti. Subjekt je konkretno jedinstvo pojedinačnih određenja, a predikat je opće određenje pridano subjektu, na temelju kojega se putem kopule kao onog posebnog uspostavlja identitet subjekta i predikata. Taj je identitet međutim još izvanjski i neodređeni odnos članova suda - pojedinačnosti subjekta i općosti predikata, u kojoj se oni ujedno drže u odvojenosti. Subjekt i predikat egzistiraju za sebe neovisno o međusobnom odnosu, tj. njihov odnos nije slobodan (Enz §§ 164-168; WL II, 53-57). Izvanjski odnos prevladava se jedinstvom onog pojedinačnog (subjekta) i onog općeg (predikata) u zaključku pomoću srednjaka, koji kao ono posebno posreduje između premisa i zaglavka.

Još viši stupanj slobode pojam postiže u nauku o zaključku, točnije na prijelazu od izvanjske svrhovitosti formalnoga zaključka k unutrašnjoj svrhovitosti refleksivnoga zaključka i zaključka nužnosti. U zaključku se prevladava odvojenost subjekta i predikata tako što se oni sjedinjuju kroz srednjak. Ali to je jedinstvo u formalnome zaključku još subjektivno, a ne izvorno jedinstvo subjekta i predikata, zato što u njemu vlada subjektivna i vanjska svrhovitost, a objekt je još samo sredstvo subjektivne svrhovitosti kojoj je samo izvanjski podvrgnut. Subjekt nameće svoju subjektivnu svrhu objektu, on postavlja svoja određenja u objekt, tako da ona ne pripadaju samomu objektu, nego su mu nametnuta izvana. Da bi se prevladala konačnost vanjske svrhovitosti, nužno je prevladati objektivnost kao puko sredstvo i uzdići je do svrhe subjekta. Kada objekt postane svrha subjekta, ta svrha nije drugo nego očitovanje unutrašnjosti samoga subjekta. To je u logici moguće u zaključku nužnosti, u kojem ne vlada više izvanjska svrhovitost, nego unutrašnja svrhovitost. To da subjekt i objekt imaju isti sadržaj samo u različitim oblicima znači da je svrhovitost prevladala svoju izvanjskost i subjektivnost. Jedinstvo subjekta i objekta nije više samo postavljeno, nego je shvaćeno kao objektivno po sebi. Subjekt sada nalazi svoje očitovanje u svojem objektu, s kojim je neposredno sjedinjen. Prijelaz od vanjske k unutrašnjoj svrhovitosti ujedno je prijelaz od vanjskoga $\mathrm{k}$ unutrašnjemu jedinstvu subjekta i objekta, koje se nalazi u ideji. Izvorno jedinstvo subjekta i predikata postiže se tek nadilaženjem zaključka, kada se pojmi da je subjekt unutrašnjost objekta, a da je objekt izraz subjekta, te da je pojam u svojoj istini ideja, u kojoj su ono subjektivno i objektivno u jedinstvu.

Saberu li se svi momenti subjektivne logike, izlazi na vidjelo logički smisao slobode: samomu sebi prozirni odnos apsolutnoga pojma spram samoga sebe, koji se uspostavlja kroz odnos spram vlastitoga drugog, u kojem sebeodnosu pojam samoga sebe određuje. ${ }^{11}$

Nadilaženje nužnosti pojma koji još nije po sebi i za sebe na prijelazu iz logike biti u logiku pojma logička je osnova najprije prijelaza od prirode $\mathrm{k}$ duhu kao istini prirode, zatim prijelaza od subjektivnoga i objektivnoga $\mathrm{k}$ apsolutnomu duhu, tj. od supstancijalne slobode $\mathrm{k}$ apsolutnoj slobodi duha, kao i prijelaza u oblasti objektivnoga duha od slobode apstraktnoga prava i moralne slobode k ćudorednoj slobodi, te u ćudorednosti od obitelji i građanskoga društva $\mathrm{k}$ državi. Kao što momenti filozofije objektivnoga duha u svojem međusobnom odnosu odgovaraju momentima logike u cjelini, tako i sami momenti ćudorednosti odgovaraju momentima logike pojma: obitelj subjektivnomu pojmu, građansko društvo objektivnomu pojmu, a država ideji. ${ }^{12}$ Budući da logika u Hegela čini osnovu cijeloga sistema, i pojam slobode u oblasti objektivnoga duha temelji se u pojmu slobode zadobivenom u logici. No iako je logika osnova filozofije, filozofija se ne svodi na logiku, nego obu- 
hvaća sva tri momenta sistema. Stoga logika prikazuje samo logičku istinu slobode, ali ne i slobodu kao bit duha.

Duh se oslobađa kroz momente subjektivnoga, objektivnoga i apsolutnoga duha. Subjektivni duh je duh koji se počinje odnositi prema samomu sebi i biti pri sebi u svojoj unutrašnjosti. Objektivni duh je slobodan u svojem ozbiljenju u drugome samoga sebe kao sloboda volje, a apsolutni duh je slobodan spoznajući da je njegova drugost njegov vlastiti proizvod. Subjektivni duh oslobađa se od zatočenosti duha u prirodi i počinje biti svjestan slobode kao svoje vlastite biti. No on je još uvijek uvjetovan prirodom kao onim od čega se oslobađa, a njegova je sloboda samo apstraktna. Određujući se kao duša i svijest, subjektivni duh ostaje u svojoj unutrašnjosti, tj. samo u odnosu prema svojim vlastitim određenjima. Prema svojem završnom određenju u psihologiji subjektivni je duh za samoga sebe jesući um. Mišljenje pak kao najviši vid inteligencije, a osobito um kao najviši vid mišljenja, ukoliko je svjestan sebe kao onoga koje ono mislivo određuje kao svoj sadržaj, jest volja (Enz § 468). S određenjem duha kao volje povezano je i to da je duh na kraju svoje subjektivne forme određen kao slobodni duh ili umna volja po sebi.

11

O logičkom vidokrugu slobode u Hegela vidi Hans Friedrich Fulda, »Der eine Begriff als das Freie und die Manifestationen der Freiheit des Geistes«, u: Anton Friedrich Koch et al. (ur.), Hegel - 200 Jahre Wissenschaft der Logik, Meiner Verlag, Hamburg 2014., str. 15-41; Franz Knappik, Im Reich der Freiheit, Walter de Gruyter, Berlin - New York 2013.; Robert B. Pippin, »Begriffslogik als Logik der Freiheit«, u: Anton Friedrich Koch, Alexander Oberauer, Konrad Utz (ur.), Der Begriff als Wahrheit. Zum Anspruch der Hegelschen Subjektiven Logik, Ferdinand Schöningh, Paderborn 2003., str. 223-237; Franco Biasutti, »Sulla determinazione logico-sistematica del concetto di libertà«, u: Franco Chiereghin (ur.), Filosofia e scienze filosofiche nell'Enciclopedia hegeliana del 1817, Verifiche, Trento 1996., str. 147-212; Gwendoline Jarczyk, Systeme et liberté dans la logique de Hegel, Aubier-Montaigne, Pariz 1980.; Emil Angehrn, Freiheit und System bei Hegel, Walter de Gruyter, Berlin - New York 1977.; Woflgang Marx, »Die Logik des Freiheitsbegriffs «, Hegel-Studien 11 (1976), str. 125-147.

12

O svezi između logike i filozofije prava, tj. o uvidu u položaj filozofije prava u cjelini sistema vidi: Thom Brooks, Hegel's Political Philosophy. A Systematic Reading of the Philosophy of Right, Edinburgh University Press, Edinburgh 2007.; Karl-Heinz Ilting, »Die logische und systematische Form der Rechtsphilosophie«, u: Karl-Heinz Ilting, Aufsätze über Hegel, Humanities Online, Frankfurt na Majni 2006.; Emil Angehrn, »Die Entwicklung des Begriffs in Hegel's Rechtsphilosophie«, u: Emil Angehrn, Dialektischer Negativismus, Suhrkamp, Frankfurt na Majni 1992., str. 304-322; Angelica Nuzzo, Rappresentazione e concetto nella 'logica' della Filosofia del diritto di Hegel, Guida, Napulj 1990.; Henry S. Richardson, »The Logical Structure of Sittlichkeit: A Reading of Hegel's Philosophie of Right «, Idealist Studies 19 (1989) 1, str. 62-78, doi: https://doi.org/10.5840/ idstudies 19891911; Vittorio Hösle, Hegel's System: Der Idealismus der Subjektivität und das Problem der Intersubjektivität I, Meiner Verlag, Hamburg 1988., str. 60-127; Klaus Hartmann, »Toward a New Systematic Reading of Hegel's Philosophy of Right «, u: Zbigniew Andrzej Pelczynski (ur.), The State and Civil Society: Studies in Hegel's Political Philosophy, Cambridge University Press, Cambridge 1984., str. 114-136; Karl-Heinz Ilting, »The Dialectic of Civil Society«, u: Z. A Pelczynski (ur.), The State and Civil Society, str. 211-226; Henning Ottmann, »Hegelsche Logik und Rechtsphilosophie: Unzulängliche Bemerkungen zu einem ungelösten Problem«, u: Dieter Henrich, Rolf-Peter Horstmann (ur.), Hegels Philosophie des Rechts. Die Theorie der Rechtsformen und ihre Logik, Klett-Cotta, Stuttgart 1982., str. 382-392; Dieter Henrich, »Logische Form und reale Totalität: Über die Begriffsform von Hegels eigentlichem Staatsbegriff«, u: D. Henrich, R.-P. Horstmann (ur.), Hegels Philosophie des Rechts, str. 429-450; Lu de Vos, »Die Logik der Hegelschen Rechtsphilosophie: eine Vermutung «, Hegel-Studien 16 (1981) 1, str. 99-121; Udo Rameil, »Sittliches Sein und Subjektivität: zur Genese des Begriffs der Sittlichkeit in Hegels Rechtsphilosophie «, Hegel-Studien 16 (1981) 1, str. 123-162; Kenley R. Dove, »Logik und Recht bei Hegel«, Neue Hefte für Philosophie 17 (1979), str. 89-108. 
Slobodna volja dosegnuta na kraju subjektivnoga duha razlikuje se međutim od slobodne volje u oblasti objektivnoga duha. Prijelaz od subjektivnoga $\mathrm{k}$ objektivnomu duhu, tj. ozbiljenje slobode u onom objektivnom, omogućen je time da duh kao slobodna volja više nije samo za sebe, nema samo slobodu kao svoju bit, nego je ta bit ujedno i svrha njegovog sebeodređenja. Objektivni duh je takva slobodna volja koja sebe zna i voli kao slobodnu, svoju slobodu čini svojom svrhom. Za razliku od subjektivne volje, ona samu sebe objektivira, a to znači ozbiljuje kroz objektivnost onoga voljenog.

U filozofiji objektivnoga duha volja se otkriva kao osnovno određenje duha. ${ }^{13}$ Kada se filozofija objektivnoga duha naziva filozofijom prava, pravo nije shvaćeno u uskom juridičkom smislu, nego obuhvatno kao postojanje slobode volje u svim mogućim njezinim oblicima (GPR § 29). ${ }^{14}$ Za razliku od objektivnoga u apsolutnome duhu nad voljom prevladava mišljenje. No u Hegela volja nije nešto odvojeno od mišljenja, nego upravo poseban način mišljenja, odnosno misleća volja ili mišljenje koje samomu sebi daje postojanje. Obratno, mišljenje se misleći ono mislivo odnosi ujedno spram samoga sebe i u onom mislivom jest pri samome sebi. Njegova su određenja određenja onoga mislivog samog. Mišljenje tako samoga sebe određuje kao volju (Enz § 468 Z), štoviše ono je supstancija volje pa stoga nema mišljenja bez volje.

U oblasti objektivnoga duha sloboda se shvaća kao sloboda volje. Volja pritom nije supstrat slobode, a sloboda nije tek svojstvo volje, nego je njezino temeljno određenje, tj. supstancija ili bit volje. Budući da je volja očitovanje duha, ona je kao takva slobodna i mogući su samo različiti stupnjevi njezine slobode (Enz § 4 Z; Enz § 382-383; usp. § 301). Zato se od volje, koja je ono navlastito duhovno, strogo razlikuju nagon, sklonost i žudnja, a zatim i prirodna volja subjektivnoga duha, koja je slobodna samo po sebi. Slijedom toga, bez slobode ne bi bilo moguće pravo, moral i ćudoređe. Shodno tim trima glavnim likovima slobode razlikuju se i tri razvojna stupnja volje: neposredna i po sebi jesuća volja, zatim reflektirajuća i za sebe jesuća volja i napokon po sebi i za sebe jesuća supstancijalna volja. U skladu s unutrašnjom raščlambom objektivnoga duha na apstraktno pravo (GPR $\S \S 34-104)$, moralnost (GPR $\S \S 105-141)$ i ćudorednost (GPR $\S \S 142-360$ ), početna apstraktna sloboda razvija se k sve određenijoj slobodi. Sloboda se razvija od osobne slobode i slobode izbora preko moralne do ćudoredne slobode. Apstraktno pravo, moralnost i ćudorednost su stupnjevi jedinstvenoga razvoja i ozbiljenja slobode. U prijelazu k višemu stupnju otkriva se nedostatnost i proturječnost prethodnoga, ali se on ne odbacuje nego se prevladava, čuva i uzdiže.

Sloboda volje sastoji se u sebeodređenju volje. Već i najnerazvijenija sloboda volje određuje samu sebe u određenoj mjeri. S daljnjim razvojem ona to čini u sve većoj mjeri i dospijeva na koncu do potpunoga sebeodređenja. Isprva apstraktno sebeodređenje volje, svojstveno nižim stupnjevima objektivnoga duha, postupno se produbljuje do takvog sebeodređenja koje u sebi obuhvaća drugost kao svoju vlastitu drugost.

Sloboda volje najprije se pojavljuje kao sloboda izbora. To je najnerazvijenije sebeodređenje volje. Tri su glavna svojstva toga pojma slobode: volja je slobodna zato što nije vezana ni za koji poseban izbor, zatim volja je slobodna jer se može odrediti za neki poseban izbor nasuprot svim mogućim drugim izborima, i napokon volja je slobodna jer i onda kada se je odredila za neki izbor opet može odustati od njega. Sloboda izbora međutim nije uistinu slobodna jer je ograničena u odnosu na sadržaj i predmet volje. Volju u njezinom biranju određuju nagoni, porivi, želje, žudnje i sklonosti, kojima je nesvjesno 
određena i kojima ne može vladati (GPR § 11). Sloboda izbora ograničena je nadalje i time da je ovisna o predmetima koji su joj ponuđeni na izbor i ne vlada time hoće li predmeti potrebni za zadovoljavanje volje biti dostupni ili ne (GPR § 13-15). Sloboda međutim zahtijeva da sadržaj volje bude određen samom voljom i da joj postane vlastit, a ne tek dan i slučajan. Uslijed navedenih dvaju ograničenja sloboda volje kao sloboda izbora u sebi je proturječna. Volja na daljnjem putu svojega oslobođenja treba dakle prevladati tu dvostruku ograničenost neosvještenim nagonima i danim ili uskraćenim vanjskim predmetima.

Sloboda izbora je proizvoljnost. U proizvoljnosti volja nije zbiljski slobodna jer je od onog voljenog i od nagona izvanjski i slučajno određena u svojem izboru. Samo volja koja je određena samom sobom i za svoj predmet ima samo samu sebe jest istinski slobodna volja. Proizvoljnost je nasuprot tomu relativno slobodna volja, koja voli nešto ograničeno. Sloboda koja pripada takvoj volji je apstraktna ili formalna sloboda, a ne istinska sloboda (GPR § $10 \mathrm{Z}, \S 13 \mathrm{Z}, \S 15 \mathrm{Z}) .^{15}$

Temeljno pitanje filozofije prava jest kako volja može voljeti istinski slobodno, a ne proizvoljno. Cjelokupni razvoj objektivnoga duha svodi se na to da se u volji prevlada proizvoljnost. Apstraktno pravo je prvo određenje slobode volje. Ono je neposredno postojanje slobode (GPR § 40). To je oblast prava na život i prava na vlasništvo. U posjedovanju vlasništva početno se izražava volja kao sebeodređenje, tj. prisvajanje svojega sadržaja i predmeta koji su isprva izvanjski i ograničavajući. Volja ne opstoji samo sama za sebe nego i vanjski kao vlasništvo spram kojega se odnosi. Tu se javlja i određenje osobnosti jer apstraktna volja za posjedovanjem vlasništva pripada pojedinačnoj osobi, koja se odnosi samo prema samoj sebi. Osobna je volja pojedinačna volja koja ima pravo sebe postaviti kroz vlasništvo i tako vlasništvom daje

13

Pregledan prikaz odnosa među momentima Hegelove filozofije objektivnog duha daje Karl-Heinz Ilting, »Die Struktur der Hegelschen Rechtsphilosophie«, u: M. Riedel (ur.), Materialien zu Hegels Rechtsphilosophie II, Suhrkamp, Frankfurt na Majni 1975., str. 5278. Cjelovite prikaze pojma slobode u Hegelovoj filozofiji objektivnog duha koji, međutim, ne obuhvaćaju slobodu u logici i filozofiji apsolutnoga duha, vidi u: Christian Krijnen, »Die Wirklichkeit der Freiheit begreifen«, Folia Philosophica 39 (2018), str. 37-144; Klaus Vieweg, Das Denken der Freiheit. Hegels Grundlinien der Philosophie des Rechts, Wilhelm Fink, München 2012.; Paul Franco, Hegel's Philosophy of Freedom, Yale University Press, New Haven 1999.; Alan Patten, Hegel's Idea of Freedom, Oxford University Press, Oxford 1999.

14

Mjesta iz Hegelovih Osnovnih crta filozofije prava navode se prema izdanju: Georg Wilhelm Friedrich Hegel, Gesammelte Werke, sv. 14/1, Grundlinien der Philosophie des Rechts, Elisabeth Weisser-Lohmann, Klaus Grotsch (ur.), Meiner Verlag, Hamburg 2009. a označavaju se kraticom GPR i brojem paragrafa. Oznaka $Z$ stoji za dodatak uz paragraf (Zusatz).

15

U § 20 propedeutičkoga spisa iz filozofije prava za nürnberšku gimnaziju Hegel razlikuje apsolutno slobodnu i relativno slobodnu volju: »Apsolutno slobodna volja razlikuje se od relativno slobodne ili proizvoljnosti po tome što apsolutna za svoj predmet ima samo samu sebe, a relativna nešto ograničeno. Relativnoj volji, npr. žudnji, stalo je samo do predmeta. Apsolutna se međutim razlikuje i od svojevolje. Ova s apsolutnom ima zajedničko to da i njoj nije stalo samo do stvari, nego štoviše do volje kao volje, upravo da se njezina volja respektira. Te dvije volje treba dobro razlikovati. Tko je svojevoljan, ostaje pri svojoj volji samo zato što je to njegova volja i nema nek uman razlog za to, tj. njegova volja nije nešto općevažeće.« - Georg Wilhelm Friedrich Hegel, Gesammelte Schriften, sv. 10.1, Nürnberger Gymnasialkurse und Gymnasialreden (1808-1816). Unterklasse Rechts- Pflichtenund Religions-Lehre aus den Schuljahren 1809/10 bis 1815/16, Klaus Grotsch (ur.), Meiner Verlag, Hamburg 2006. 
samoj sebi vanjsko i objektivno postojanje slobode. Osobnost je doduše slobodna, ali ta je sloboda osobnosti još apstraktna jer se sastoji u apstrakciji od svega određenog, svakog konkretnog ograničenja (GPR § 41).

Volja apstraktnoga prava prisvaja svoj predmet prvo u vidu vlasništva, ali ona i dalje ostaje proizvoljna i ograničena na pojedinačnu osobu. Prijelaz od vlasništva k ugovoru zbiva se tako da se volja ne odnosi samo prema vlasništvu koje posjeduje, nego također i prema volji druge osobe. Vlasništvo je sada uvjetovano time da ga i druga volja kroz ugovor prizna vlasništvom. Na osnovi proizvoljnosti slobode izbora, tj. na osnovi mogućnosti da slobodna volja ne poštuje ugovor, nastupa kazna kao treći stupanj apstraktnoga prava. Apstraktno pravo mora se utvrditi ugovorom, koji sadrži i odredbe kazne za njegovu povredu. Slobodna volja kaznu prihvaća kao vlastitu kaznu, a ograničenja koja ona nameće kao sebeograničenja. ${ }^{16}$

Osoba međutim ne prisvaja samo vanjsko vlasništvo nego posredstvom njega i samu sebe. Prisvajajući svoju osobnost osoba ju oslobađa od vanjskosti kojom je porobljena. Ukoliko je vlasništvo način postojanja volje, odnos dviju volja prijelaz je od vlasništva k ugovoru. U ugovoru nije više presudan odnos volje prema nečem voljenom, nego odnos volje prema drugoj volji. U njemu osoba nema vlasništvo nad voljenim samo po vlastitoj volji, nego i po drugoj volji, tj. po zajedničkoj volji. Ta zajednička volja na kojoj se zasniva ugovor međutim još uvijek nije opća volja, nego je volja dviju osoba. Kršenje ugovora i prava na vlasništvo moguće je zato što su ga sklopile posebne osobne volje. Takvo uzrokovanje neprava je kršenje same slobode. Poštujući osobnu slobodnu volju koja je počinila prekršaj i time negirala slobodu, odgovarajuća kazna je negacija negacije slobode i ponovna uspostava prava i slobode. Kazna je ukidanje prekršaja, a time i očuvanje zajedničke volje.

Prijelaz od apstraktnoga prava k moralnosti izazvan je time što je prisila ugovora koji prijeti apstraktnom kaznom u proturječju sa slobodom volje. ${ }^{17}$ Sloboda izbora otkriva se kao sloboda koja pripada pojedinačnoj volji koja ne može samu sebe u potpunosti odrediti jer se podvrgava apstraktnomu pravu, koje ne dopire do opće volje. U slobodno birajućoj volji još uvijek je razdvojeno ono opće i pojedinačno. Zbog toga ona ne može imati unutarnji sadržaj i ostaje puko osobna i proizvoljna. Općost apstraktnoga prava apstrahira od posebne osobne volje i ostaje ravnodušna prema njezinim posebnim interesima. Obratno, osobna volja koja se podvrgava odredbama apstraktnoga prava ne može voljeti ono opće. Zajednička osobna volja je izvanjski odnos utoliko što se zasniva na odnosu spram vlasništva kao vanjskoga predmeta. Ugovorni odnos je u osnovi proizvoljan i nužno je prijeći na viši stupanj slobode volje kako bi se volja oslobodila od proizvoljnosti.

Da bi se sloboda volje produbila, volja se mora ograničiti zakonom, koji joj se više ne pojavljuje kao vanjska prisila kazne. To više nije odredba apstraktnoga prava, nego moralni zakon, koji nije izvanjski nametnut volji, nego ga volja iznutra priznaje. To je takav zakon koji slobodna volja sama sebi daje postavši samozakonodavnom. Moralna je volja posebna volja koja po svojem najvišem određenju voli ono opće i pri tome je slobodna jer tomu općemu nije podvrgnuta. Ona se odnosi spram onoga općeg kao spram svojega vlastitog sadržaja. Osoba se u moralnosti uzdiže do subjekta pa moralna volja postaje volja moralnoga subjekta, a moralnost nije drugo nego razvoj prava subjektivne volje (usp. GPR § 107). Pravo posebnosti subjekta je pravo subjektivne slobode. Volja se tu ne teži objektivirati u nekom vanjskom predmetu, nego svoje postojanje ima u samoj sebi, svoju određenost ima u svojoj nutrini, u 
svojoj subjektivnosti. Moralnost je oblast subjektivne volje koja može priznati ono voljeno samo ako joj je ono nešto vlastito, tj. ako je volja prisutna u voljenom kao subjektivnost. Subjektivna volja je moralno slobodna utoliko što određenja volje postavlja iznutra kao svoja vlastita određenja. Sloboda se stoga u moralnosti shvaća kao refleksija volje u sebe, tj. kao sebesvjesni odnos volje spram same sebe.

Ukoliko je djelovanje izraz moralne volje, moralnost se raščlanjuje na tri oblika moralnoga djelovanja: apstraktno djelovanje ograničeno na predumišljaj i na odgovornost koja se preuzima za to djelovanje, zatim djelovanje s namjerom, napose sa svrhom osobnoga blagostanja, te napokon djelovanje poradi onog dobrog, u kojem se subjektivna volja uzdiže do onog općeg. Volja postavlja sebi svrhe kao svoj sadržaj, a ozbiljene svrhe nose u sebi određenje subjektivnosti kroz predumišljaj i namjeru. Predumišljaj i namjera nalaze se u unutrašnjosti volje, i ona je moralno odgovorna utoliko što ih u sebi sadrži. Oslobađanje volje počinje formalnim priznanjem onoga predumišljenog, zatim se nastavlja priznanjem onog namjeravanog, a završava pounutrenjem i iščezavanjem svake vanjskosti u moralu. Subjektivna volja sve više određuje to što priznaje kao vlastito u svojem predmetu, tako da na koncu ono voljeno postaje ono dobro kao ono opće. Ukoliko voli ono dobro, moralna volja doseže najviši mogući stupanj svoje slobode.

Kroz sva tri navedena djelovanja volja voli povratak k samoj sebi u drugome. U prvome se razlučuje ono što je dano i ono što je voljno proizvedeno. Odgovornost se preuzima samo za ono potonje, ali djelovanje ima i udaljene učinke u kojima volja ne određuje samu sebe. U drugome se razlučuje ono što je dano izvana kao opća volja i unutrašnje posebno određenje toga općega, ono što volja postavlja kao svrhu svojega djelovanja (blagostanje). U trećem je namjera ujedno opći sadržaj jer ono dobro je namjera uzdignuta do pojma volje. Tu u završnom dijelu moralnosti sadržaj volje u potpunosti je određen samom voljom, štoviše sama je slobodna volja učinjena sadržajem volje (GPR § 121 Z). Voljeti ono dobro je voljeti sebeodnos u djelovanju volje, tj. voljeti izvršenje slobodne volje. Volja se tu odnosi prema samoj sebi u svojem djelovanju i na taj način određuje samu sebe. Moralno dobro je supstancija subjektivne volje. Voleći ono dobro volja ima sadržaj koji je istovjetan s njom samom, te voli svoju vlastitu slobodu i ozbiljuje je u svojem djelovanju.

U moralnoj slobodi volja se potpuno oslobađa od nagona i sklonosti. Sama sebi dajući svoj zakon ona sama sebi daje i svoj sadržaj, sama je uzrok svojega djelovanja. Sadržaj volje postaje volji nužan kao njezina svrha, a nije više slučajan kao u slobodi izbora. Načelo moralnosti je za sebe beskonačna subjektivnost slobode, dakle, subjektivnost koja je postavljena u odnos prema samoj sebi i nije više apstraktna, nego je svjesna svoje slobode. No iako moralna volja sama određuje svoje svrhe jer se je oslobodila od neposrednih

16

Usprkos tomu što je ovdje riječ o ugovoru i kazni za kršenje ugovora, zakoni i sudovi u smislu pravnoga sustava mogući su tek na razini građanskoga društva, a ne na razini apstraktnoga prava. Ugovorni odnos kao moment apstraktnoga prava nije društveni odnos, koji podliježe zakonima, nego odnos dviju apstraktnih osoba, a to znači osoba apstrahiranih od društva. Shodno tomu, vlasništvo se istom na razini građanskoga društva promatra sa stajališta sistema potreba, a kao moment apstraktnoga prava ono je prvi stupanj na putu sebeoslobađanja volje od puko osobne volje.

17

Izlaganje konkretne kazne uslijedit će na stupnju građanskoga društva, gdje je riječ o kršenju zakona, kojim se ugrožava ćudoredna sloboda na razini društva (GPR $\S \S 219-220$ ). 
određenja nagona, te svrhe još uvijek nisu sebeodređenja same volje. Volja je još ovisna o svojim sadržajima, koji doduše više nisu izvanjski dani, ali su zato još uvijek iznutra dani (Enz § 478; usp. GPR § 15). Sloboda moralne volje je samo negacija neposrednog sebeodređenja slobode izbora. Stoga ni ona nije potpuno samostalna i sebeodređujuća. Ona još nije istinski ili apsolutno slobodna volja, nego je samo relativno i apstraktno slobodna jer za svoj predmet nema samu sebe nego nešto drugo nasuprot sebi (GPR § $20 \mathrm{Z}$ ). U njoj još uvijek postoji razdvoj subjekta i objekta volje, onog volećeg i onog voljenog (GPR § 7).

Moralna volja je apstraktna, ograničena i formalna utoliko što ono opće za nju ostaje još uvijek nešto tuđe i apstraktno. U moralnosti vlada proturječje između općosti moralnoga zakona i posebnosti djelovanja i dužnosti. Stoga moralnost ostaje na stajalištu trebanja i zahtijevanja. Subjektivna volja ne može biti posve pri sebi u svojem djelovanju jer se u njemu odnosi samo prema samoj sebi. Formalizam moralnosti sastoji se u tome da se slobodna volja odnosi prema drugome samo posredstvom svojega djelovanja. Sebeodnos volje i voljno djelovanje ostaju razdvojeni, što znači da djelovanje ne može posve ozbiljiti ono opće.

Nedostatak moralne slobode čini nužnim prijelaz k ćudorednosti. Subjektivna volja u apstraktnome pravu i moralu samo je još formalna i apstraktno slobodna jer je takva volja samo forma zbiljske i konkretne slobode, koja se postiže istom u ćudoređu. Ondje volja postaje uistinu slobodnom jer se opća volja izvršava kroz pojedinačnu volju, a pojedinačna volja prisvaja ono opće kao svoju vlastitu svrhu. Ono opće nije tek ono koje obuhvaća ono pojedinačno, nego potpuno sebeodređenje općega u pojedinačnome. Ono pojedinačno s druge strane nije tek onomu općem podređeno, nego se određuje unutar općega.

Ćudoredna sloboda, tj. istinska sloboda volje, moguća je jedino u istinskoj zajednici. U ćudorednosti se ukida jednostranost apstraktnog prava i moralnosti, prevlast objektivnosti nad subjektivnošću i obratno prevlast subjektivnosti nad objektivnošću. Istom se tu nadilazi apstraktnost subjektivne volje i volja postaje konkretnom. Ćudoredna volja nije tek subjektivna volja, jer ima svoj vlastiti pojam, naime slobodu, kao svoj sadržaj. Jedina svrha takve istinski slobodne volje jest sama sloboda volje. Ćudoredna volja voli istinsku zbiljnost svoje slobode. Time je ona ujedno temelj prethodnih dvaju stupnjeva objektivnoga duha.

Sloboda volje očituje se u obitelji tako da je volja pri sebi u članovima obitelji kao onome drugom same sebe, slično kao što je organizam u cjelini u svim svojim organima, a svaki je pojedini organ to što jest samo u odnosu prema svim drugim organima i cjelini organizma. Obitelj je jedinstvo ljubavi. Nadilazeći volju za zadovoljavanjem neposrednih potreba u drugome, članovi obitelji u jedinstvu ljubavi nadilaze volju kao proizvoljnost. U tom se jedinstvu ne gubi posebnost onih sjedinjenih, nego svako od njih zadobiva sebe u onome drugom ostajući pri samome sebi. Time se u obitelji kao prvome stupnju ćudorednosti ozbiljuje sloboda koja nadilazi moralnu slobodu (Enz $\S 158 \mathrm{Z}$ ). Obitelj je, s druge strane, u odnosu na više stupnjeve ćudorednosti ograničena zajednica po tome što je ona zajednica neposrednoga i prirodnoga ćudorednog duha, a njegova neposrednost sastoji se u tome da se sloboda $\mathrm{u}$ obitelji ozbiljuje prvenstveno u obliku čuvstva.

Građansko društvo sveza je samostalnih pojedinačnih volja u formalnoj općosti, na osnovi sustava potreba i pravnoga sustava kao sredstva za osiguranje prava. U volji građanskoga društva tako dolazi do razdvajanja općega i 
pojedinačnoga. Tu se s jedne strane javlja posebna konkretna osoba sa svojom subjektivnom slobodom, koja je posebna svrha samoj sebi i u kojoj se zadovoljavaju posebne potrebe, a s druge strane ono opće pod vidom izvanjske i samo interesne povezanosti međusobno neovisnih pojedinaca. Sloboda zadovoljavanja potreba nije istinska sloboda jer ćudoredna sloboda još nije $u$ potpunosti oslobođena od momenta proizvoljnosti.

Na kraju razvoja objektivnoga duha u državi ozbiljuje se istinski slobodna volja. To više nije ni samo posebna ni samo zajednička nego opća supstancijalna volja, tj. volja u kojoj se posebna volja uzdiže do onoga općeg i uspostavlja opću volju. Općost je sadržaj istinski slobodne volje, koja ne izvodi svoj sadržaj iz nečeg drugog od same sebe, nego iz samoga pojma volje, odnosno iz slobode. To je potpuno slobodna volja, koja voli samu sebe, to jest svoju slobodu. Supstancijalna volja je umska volja jer je prozirna samoj sebi, misli samu sebe i zna svoj pojam, te voli u skladu s tim znanjem (Enz § 481). Ćudoredna sloboda koja se ozbiljuje kroz supstancijalnu volju jest supstancijalna sloboda, u kojoj je odstranjena svaka proizvoljnost (GPR § 257). Nasuprot formalnoj slobodi građanskoga društva, koje poznaje samo formalnu općost, supstancijalna sloboda nije suprotstavljena i odvojena od subjektivne slobode, nego je s njom sjedinjena. ${ }^{18}$ Država je potpuno ozbiljenje slobode jer svojom općom voljom ostaje pri sebi u posebnim voljama kao svojim momentima (GPR $§ 258 \mathrm{Z}$ ). Istovremeno posebne volje voleći ono opće kao vlastitu supstanciju i svrhu postižu u državi svoju konkretnu slobodu (GPR § 260).

Filozofija objektivnoga duha dakle uključuje ne samo izlaganje potpuno razvijenoga pojma slobode volje (ćudorednost) nego i prethodni prikaz ograničenosti slobode volje, zatim prevladavanje proturječnosti u slobodi volje kao apstraktnopravnoj volji i moralnoj volji te oslobođenje volje u ćudorednosti. Ćudorednost kao završni stupanj objektivnog duha najviši je stupanj slobode volje. Istinski slobodna, a to znači umna volja, postignuta u ćudoređu, razlikuje se od relativno slobodne volje po tome što apsolutna ima samo samu sebe, a relativna nešto ograničeno za svoj predmet. U apstraktnome pravu volja kroz osobu voli vlasništvo kao svoj vlastiti objekt. U moralnosti se pak volja izražava kroz djelovanje te se odnosi prema sebi u svojem djelovanju. U ćudorednosti napokon volja je volja onoga općeg kao njome proizvedenoga.

Tri stupnja volje raščlanjuju se prema momentima logike: 1. neposrednost bez izričitog odnosa spram drugoga (apstraktno pravo); 2. refleksija ili posredovanje, u kojem se ono neposredno posreduje svojim drugim (moralnost); 3. posredovana neposrednost ili jedinstvo prethodnih dvaju momenata (ćudoređe). Apstraktno pravo i moralnost jednostrani su jer apstraktnomu pravu nedostaje moment subjektivnosti, a moralu moment objektivnosti. Oni su ujedno apstraktni momenti ćudorednosti, a sve troje su oblici postojanja slobodne volje. Ćudorednost je jedinstvo i istina prvih dvaju stupnjeva, u njoj je sloboda i subjektivna i objektivna, slobodna volja je supstancijalna volja, tj. volja koja ima zbiljnost u skladu sa svojim pojmom, volja koja jest po sebi i za sebe. Ćudorednost je sebeodređenje volje koje za svoj sadržaj ima svoj vlastiti pojam, naime slobodu. Budući po sebi i za sebe istinski slobodna, ta

GPR § 258: »Umnost se sastoji, apstraktno promatrano, općenito u jedinstvu općosti i pojedinačnosti koje se prožima, i tu konkretno po sadržaju u jedinstvu objektivne slobode, tj. opće supstancijalne volje i njezinih posebnih svrha - stoga po formi u djelovanju koje se određuje prema mišljenim, to znači općim zakonima.« 
se volja ne odnosi spram onog voljenog kao spram nečega što je izvan nje, nego spram same sebe.

Stupnjevi slobode volje prikazuju se u svezi s trima logičkim kategorijama - opće, posebno i pojedinačno. Najprije je slobodna volja shvaćena na način apstraktne pojedinačnosti kao volja koja voli svoj predmet. Sljedeći je stupanj volja na način apstraktne općosti, u kojoj volja u voljenome voli samu sebe. Treći stupanj slobode volje je sjedinjenje onoga općeg i pojedinačnog. Volja se oslobađa od apstraktnog odnosa, vanjski određenog onim voljenim, ali i od apstraktne općosti u sebe zatvorene volje, prema istinskoj slobodi, koja podrazumijeva jedinstvo unutrašnjega i vanjskoga, subjektivnoga i objektivnoga, pojedinačnoga i općega. Tu volja hoće nešto na taj način da pritom ne prestaje biti opća, odnosno da ostaje pri sebi. Sloboda je voljeti nešto određeno, pritom biti pri sebi u toj određenosti i vratiti se k općemu. Ona je biti pri sebi u drugome samoga sebe (GPR § 7 Z).

Određena nagonima, žudnjama i sklonostima volja je slobodna samo po sebi, a ne i za sebe. To je prirodna volja, koja postoji kao nagon. Na razini refleksije volja postaje slobodna za sebe jer može stajati iznad svojega sadržaja i načina njegovog postignuća. Sloboda koja pripada refleksivnoj volji još uvijek je međutim nedostatna jer je ta volja u proturječju sa svojim sadržajem. Sadržaj nije potpuno određen kao vlastit. Ono voljeno je nešto dano, a ne određeno voljom. Proturječje između volje i onog voljenog prevladava se ondje gdje se postiže njihovo jedinstvo. Volja tada jest po sebi i za sebe, sebeodređujuća općost. Volja je tek tu potpuno pri sebi jer se odnosi samo prema samoj sebi, tako da je otklonjen svaki odnos prema nečem drugom, koje bi bilo neovisno o volji.

Volja je uvijek sebeodnos i ujedno odnos spram nečega drugoga, sebeodređivanje i određivanje objekta ili sadržaja volje. Voleći nešto posebno volja se isprva odvraća od same sebe i samu sebe određuje i uposebljuje onim što nije ona sama. Ono voljeno je ograničenje volje jer ona voleći njega ne može voljeti ništa drugo. Tada voljenje nije određeno volećom voljom nego onim voljenim. Takva volja koja ne može postići jedinstvo sebeodnosa i odnosa spram drugoga jest prirodna volja. Ona je neposredno istovjetna sa svojim nagonom i sklonošću kao svojim određenjem. Ta se volja ne može svjesno odnositi prema samoj sebi jer joj je objekt neposredno dan, a nije određen njom samom. Ipak, već i prirodna volja sadrži moment sebeodnosa na način nagona za prisvajanjem objekta i zadovoljavanjem potrebe. Proizvoljna volja sastoji se u svijesti da volja nije vezana za neki određeni sadržaj, nego da je svaki sadržaj predmet izbora. Ona je posve formalna, a sadržaj joj je vanjski dan i ne proizlazi iz nje. Negirajući svoj poseban sadržaj volja je puko refleksivna. Ona je pri sebi tako da apstrahira od svega voljenog beskonačno negirajući ono što bi je moglo odrediti. Ona stoji iznad svojega sadržaja i zato beskonačno prelazeći s jednoga na drugi konačan sadržaj ostaje beskonačno nezadovoljena. Ono voljeno uvijek je nešto drugo od same volje te joj postaje nešto slučajno. Istinska beskonačnost nije negacija drugoga, nego biti pri sebi u drugome. Sloboda je voljeti nešto određeno i biti pri sebi u toj određenosti. Odnos spram sebe i spram drugoga su samo dvije strane istoga odnosa. Odnos volje prema nečem drugom od nje same ujedno je sebeodnos. Samo takav odnos uspostavlja istinsku slobodu volje.

Mišljenje u tom oslobođenju volje ima presudnu ulogu. Štoviše, volja se uzdiže $\mathrm{k}$ mišljenju, a a mišljenje se potvrđuje u volji. To je sebesvijest volje o svojoj slobodi. Takva volja je beskonačna jer u voljenome nema svoje ograničenje. Ona je istinska jer njezin sadržaj odgovara njezinomu pojmu. Ona je 
opća, ne kao nešto zajedničko što stoji izvan pojedinačnoga, nego kao konkretno opće koje se uposebljuje. Ona je umna jer ima svoju bit kao svoje određenje i svrhu te zna samu sebe kao slobodnu i voli sebe kao svoj predmet. Volja je istom kao mišljenje istinska volja i istinski slobodna. ${ }^{19}$

Ali na kraju ćudorednosti preostaje još nesloboda koju objektivni duh kao takav ne može nadići. Sloboda je na stupnju objektivnoga duha uvijek ograničena jer se pojavljuje kao sloboda volje. Na kraju objektivnog duha pokazuje se proturječnost slobode volje kao takve. S jedne strane sadržaj volje je njezin vlastiti sadržaj, a s druge strane volja pretpostavlja ono voljeno koje ostaje nešto drugo od nje premda s njom sjedinjeno. Samoozbiljenje duha zahtijeva napokon da se nadiđe sloboda volje kao takva jer ona nije u stanju u potpunosti odrediti svoj sadržaj. ${ }^{20}$ Volja se sama po sebi nikada ne može osloboditi od svoje konačnosti jer ono voljeno koje volja voli neko je ograničenje i negacija. Da bi naime volja uopće bila voljom, ona mora sebe ograničavati (GPR § 6 Z). Volja ne može ništa ne voljeti, kao što ne može biti potpuno određena onim voljenim. Ona pretpostavlja uvijek razliku između onog volećeg (subjekta) i ono voljenog (objekta) koje mu se suprotstavlja. U svojem sebeodređivanju volja je uvijek i određivanje i neodređenost, voljenje nečeg određenog i biti pri sebi u tom određivanju. Voleći nešto određeno volja je pri sebi i odnosi se prema sebi.

Istom je apsolutni duh onaj lik duha u kojem je on u svojoj zbiljnosti samooslobođen za svoj pojam te je postao apsolutnom slobodom. Sva tri lika apsolutnoga duha - umjetnost, religija i filozofija - na svoj način nadilaze slobodu volje, ali među njima je filozofija najslobodniji lik duha. ${ }^{21}$ Ona određuje cijeli svoj sadržaj posve iz same sebe, nema ničega posve drugoga od sebe jer je njezino sebeodređenje slobodno od zrenja (umjetnost) i predstavljajućeg mišljenja (religija), ali i od svakog mogućeg subjektivnog predstavljanja i njemu suprotstavljenih vanjskih predmeta. Ono apsolutno se u umjetnosti zre u svojoj ljepoti, u religiji se predstavlja u svojoj svetosti, a u filozofiji se poima u svojoj istini kao apsolutni duh. Odatle postoji unutrašnja veza između slobode i mišljenja, napose uma, umskoga mišljenja u razlici prema razumskome mišljenju. Um je jedini u stanju doprijeti do slobode kao biti duha, a time i do istinske slobode. Sebeoslobođenje duha stoga nije drugo nego nadilaženje ne samo svih nižih duševnih moći (žudnje, čuvstva i volje) nego i svih konačnih likova znanja, kako osjetilnog znanja tako i razuma, i uzdignuće svijesti duha do uma i apsolutne znanosti.

Kroz filozofiju kao apsolutnu znanost duh se potpuno oslobađa za slobodu kao svoju bit spoznajući da on proizvodi sve ono što nije on sam i da je to od njega samoga proizvedena njegova vlastita drugost, te da nema ničega što bi

19

Usp. GPR § 21: »Samosvijest koja svoj predmet, sadržaj i svrhu čisti i uzdiže do te općosti čini to kao mišljenje koje se izvršava u volji. Ovdje je točka na kojoj postaje jasno da volja samo kao misleća inteligencija jest istinska, slobodna volja.«

20

O ograničenosti slobode kao slobode volje Hegel u Predavanjima iz filozofije prava kaže da je volji kao takvoj nužno suprotstavljen njezin objekt, koji je stoga njezina granica.
Voljenje je konačno jer se kreće prema onom voljenom kao svojem koncu. Vidi: Georg Wilhelm Friedrich Hegel, Gesammelte Werke, sv. 26.1, Vorlesungen über die Philosophie des Rechts I, Dick Felgenhauer (ur.), Meiner Verlag, Hamburg 2014., str. 331.

21

Vidi Georg Wilhelm Friedrich Hegel, Gesammelte Werke, sv. 18, Vorlesungsmanuskripte II (1816-1831), Walter Jaeschke (ur.), Meiner Verlag, Hamburg 1995. 
bilo nezavisno od njega ili što bi ga moglo izvana ograničiti. Duh je određen kao vraćanje i vraćenost k samomu sebi iz svojega drugoga, tako da duh ukida svaku izvanjskost i prisvaja ju u svoju unutrašnjost, otkriva da ono drugo od njega nije odvojeno od njega nego je njegovo biti drugim (Enz $§ 381 \mathrm{Z}$ ).

Prije svake slobode volje, bilo slobode izbora, moralne slobode ili ćudoredne slobode, sloboda je bit duha i to kao sebesamoodređenje, koje se ne podvrgava nikakvomu izvanjskomu određenju: biti pri sebi u drugome samoga sebe, sebeodnos kroz odnos s drugim kao vlastitim drugim (Enz § $382 \mathrm{Z}$ ). U filozofiji kao dovršenju oslobođenja duha to se pokazuje tako da apsolutni duh ne trpi nikakvu danost, pretpostavljenost nekog tuđeg i izvanjskog sadržaja, da je bespretpostavan, da nije ovisan ni o čemu drugom izvan sebe, da je sam sebi temelj, svoj vlastiti početak. Stoga je apsolutno ozbiljenje slobode kao biti duha moguće istom u filozofiji kao najvišem stupnju apsolutnoga duha. Filozofija međutim kao apsolutno znanje onog apsolutnog, kao znanost slobode, još uvijek nije i sama po sebi ozbiljenje slobode kroz svijet, za koje je nužan i objektivni duh, a to znači i istinski slobodna volja, kojom se sloboda ozbiljuje kroz ćudoredni svijet, tijekom svjetske povijesti kroz različite likove objektivnoga duha kao napredak u svijesti slobode. Sloboda postignuta u filozofiji je sloboda u elementu mišljenja. Filozofija je utoliko temelj ozbiljenja slobode kroz ćudorednost, u kojoj se sloboda objektivira kao svijet duha, to jest kao svijet koji je proizveden iz samoga duha (GPR § 4). Država kao istinska umna zajednica svjetotvorno je ozbiljenje slobode, svjetskopovijesna zbiljnost slobode (GPR § 484), što je ujedno i apsolutna krajnja svrha svijeta (GPR § 549). Stupnjevi subjektivnog, objektivnog i apsolutnog duha na različit način odgovaraju slobodi kao biti duha. Objektivni duh je slobodniji od subjektivnoga, a najveća je sloboda u apsolutnome duhu. Unutar objektivnoga duha ćudorednost je slobodnija od moralnosti, dočim je unutar apsolutnoga duha religija slobodnija od umjetnosti, a filozofija je slobodnija od svih prethodnih likova duha. Filozofija je najviši i najslobodniji lik duha. U filozofiji se dovršava oslobođenje duha kao njegovo sebeosvještenje. Ozbiljenje pak slobode kroz svijet dovršava se istom u ćudorednosti utemeljenoj na filozofiji, naime u državi kao zajednici slobode. Religija je osnova onog ćudorednog uopće, a napose je osnova za ozbiljenje ćudoredne slobode u državi. Ali istinsko ozbiljenje slobode kao svijeta slobode počiva istom na slobodi duha ozbiljenoj $\mathrm{u}$ filozofiji. ${ }^{22} \mathrm{Da}$ bi duh bio istinski slobodan, on mora steći znanje slobode, a budući da je sloboda bit duha, a ozbiljenje onog apsolutnog je apsolutni duh, to znači da je apsolutno znanje isto što i znanje biti onog apsolutnog ili znanost slobode.

Gledano iz cjeline sistema, sloboda se ozbiljuje kada ono apsolutno (apsolutna ideja) slobodno proizvodeći drugo od sebe (priroda) ukine njegovu tuđinu i prisvoji ga kao svoje drugo, i vrativši se k samomu sebi (duh) održava istost sa samim sobom u drugome, odnos spram sebe kroz drugoga u mišljenju (filozofija, religija, umjetnost) i umnoj volji (pravo, moral, ćudoređe). Promatra li se sloboda u okviru filozofije duha, tj. u okviru raščlambe na subjektivni, objektivni i apsolutni duh, izlazi na vidjelo da je sloboda bit duha. Postoje različiti stupnjevi slobode koje duh postupno osvaja i nadilazi razrješavajući njihova proturječja. Cijeli razvoj duha nije drugo nego oslobađanje duha od svih oblika njegove egzistencije koji se ne slažu s njegovim pojmom, oslobađanje do zbiljnosti koja potpuno odgovara pojmu duha (Enz § $382 \mathrm{Z}$ ). Subjektivnomu duhu pripada subjektivna sloboda kao sloboda izbora neposredno danih sadržaja i svrha (neposredna ili prirodna volja), objektivnomu duhu pripada: 
formalna sloboda osobne volje (pravo), zatim formalna sloboda samozakonodavne subjektivne volje (moralnost) i napokon supstancijalna sloboda supstancijalne volje (ćudorednost), a apsolutnomu duhu pripada sloboda mišljenja.

Duh se u svojoj neslobodi, tj. u svojoj konačnosti, isprva udvaja na subjekt i objekt, na svijest i predmet svijesti. On se pojavljuje kao subjekt kojemu je suprotstavljen objekt. Oslobođenje duha stoga se zbiva kao iščezavanje tuđine objekta. Ono je ukidanje objektivne danosti i ukidanje opreke subjekta i objekta, subjektivnog i objektivnog duha i uzdignuće do apsolutnog duha. Drugim riječima, ono je prisvajanje onoga objektivnog koje se je otuđilo od duha, to jest povratak duha iz svojega otuđenja natrag $\mathrm{k}$ samomu sebi, do apsolutnog znanja o tome da su svi sadržaji subjektivnog i objektivnog duha proizvod duha kao ono drugo njega samoga. Ono drugo nije neko apsolutno drugo nasuprot sebstvu duha, nego vlastito drugo. Kao i na svim prethodnim stupnjevima sistema, sloboda je i ovdje biti pri samome sebi u drugome samoga sebe (Enz $\S 38 \mathrm{Z})$.

Na razini apsolutnoga duha pokazuje se da se sloboda kao sloboda volje i njezino ozbiljenje kao objektiviranje svodi na ozbiljenje duha, od subjektivnoga preko objektivnoga do apsolutnoga duha. Budući da je oslobađanje sebeposredovanje onoga apsolutnog samim sobom i kroz samoga sebe, sloboda se na osobit način očituje u posredujućoj oblasti duha, a to je objektivni duh. Ali različiti likovi objektivnoga duha, u kojima se ozbiljuje sloboda, momenti su ozbiljenja onog apsolutnog. Budući da je razvoj duha usmjeren $\mathrm{k}$ mišljenju, tj. spoznaji apsolutne ideje, i sama je volja u osnovi time određena i u toj određenosti postaje momentom te spoznaje. Sloboda volje počiva u slobodi kao biti duha, koja se obistinjuje ponajprije u mišljenju. Volja međutim nikad nije odvojena od mišljenja. Sloboda svojstvena volji povezana je s time da volja uvijek već uključuje neku vrstu mišljenja. Volja je štoviše osobit način mišljenja ili osobito uposebljenje mišljenja (Enz I, § 24 Z). Mišljenje je pak uvijek praćeno voljom utoliko što prisvaja mislivi predmet te time nadilazi njegovu vanjskost i tuđinu. U mišljenju je ono misleće pri sebi jer mu ono mišljeno više nije suprotstavljeno i nema navlastita svojstva neovisna o mišljenju. Volja nasuprot tomu misli tako da pretpostavlja i predstavlja sebi ono voljeno kao svoj predmet. To znači da ona ne može proizvesti unutrašnje jedinstvo subjekta i objekta. Dok objektivni duh susreće objektivnost kao ograničenje volje, kao nešto što joj se odupire, dotle apsolutni duh to ograničenje spoznaje kao nužnu određenost mišljenja, tj. kao njegovo unutrašnje ograničenje. Potpuno prevladavajući vanjskost onog objektivnog apsolutni duh prevladava konačnost svojstvenu subjektivnomu i objektivnomu duhu. On spoznaje da nasuprot njemu nema nikakve od njega nezavisne objektivnosti. Oslobodivši se za svoju istinu, apsolutni duh svjestan je da je sve ono drugo od njega proizvod njegovog sebeodređivanja. Sloboda kao sebeodređivanje apsolutnoga duha apsolutni je sebeodnos u svim svojim određenjima. Kroz sebeodnos apsolutnoga duha $\mathrm{u}$ drugome to drugo pokazuje se kao njegovo vlastito. On ostaje u drugome pri sebi i svjestan je toga sebeodnosa (Enz § 480).

Sloboda se ozbiljuje kao ozbiljenje onoga apsolutnog, koje je u svojem biti po sebi apsolutna ideja, koja izlazi iz same sebe u prirodu i vraća se k sebi u duhu, u kojem se napokon otkriva da apsolutna ideja nije drugo nego po sebi

22

Prikaz odnosa objektivnoga i apsolutnoga duha, napose filozofije, s obzirom na slobodu vidi u: Hans Friedrich Fulda, Das Recht der

Philosophie in Hegels Philosophie des Rechts, Klostermann, Frankfurt na Majni 1968. 
jesući duh. Stoga je ozbiljenje slobode kao biti duha ujedno ozbiljenje apsolutne ideje u po sebi i za sebe jesućem duhu. Ono se dovršava onda kada se dovrši razvoj duha u kojem se on oslobađa od svih likova koji ne odgovaraju slobodi kao njegovoj biti i dosegne svoj apsolutni lik i unutar njega njegov najviši stupanj - filozofiju kao znanost slobode.

\section{Igor Mikecin}

\section{Philosophie als Wissenschaft der Freiheit}

\section{Zusammenfassung}

Gemäß der Dreiteilung des Hegelschen Systems in Logik, Philosophie der Natur und Philosophie des Geistes gliedert sich auch Hegels Begriff der Freiheit. Die Freiheit ist in der Logik die Freiheit des Begriffs selbst, der sich von den Bestimmungen der Seinslogik und der Wesenslogik für die Bestimmungen der Begriffslogik befreit. Der Begriff gelangt zu seiner Freiheit in der absoluten Idee, die nichts anderes als die Idee der Freiheit ist. Auf dem logischen Freiheitsbegriff gründet die Freiheit, wie sie in der Philosophie des Geistes auf allen Stufen der Entwicklung des Geistes begriffen wird. In der Philosophie der Natur aber wird die Natur als die Negation der Freiheit und als notwendige Vermittlung der Idee der Freiheit im Fortgang ihrer Verwirklichung aufgefasst. In der Philosophie des Geistes stellt sich heraus, dass die Freiheit das Wesen des Geistes ist. Das Selbstbewusstsein des Geistes erscheint zuerst im subjektiven Geist, der sich aus der Natur befreit. Die weitere Verwirklichung des Geistes geschieht durch den objektiven Geist, der sich im abstrakten Recht, in der Moralität und Sittlichkeit objektiviert. In der Weltgeschichte, welche die letzte Bestimmung des objektiven Geistes ist, wird der Geist als der Fortschritt im Bewusstsein der Freiheit verwirklicht. Im Bereich des objektiven Geistes wird die Freiheit als die Freiheit des Willens begriffen. Der Wille ist dabei kein Substrat der Freiheit, und die Freiheit ist keine bloße Eigenschaft des Willens, sondern sie ist die Substanz oder das Wesen des Willens. Gemäß der Gliederung des objektiven Geistes in das abstrakte Recht, die Moralität und die Sittlichkeit entwickelt sich die anfängliche abstrakte Freiheit zur immer konkreteren Freiheit. Das abstrakte Recht, die Moralität und die Sittlichkeit sind die Stufen der einheitlichen Entwicklung und Verwirklichung der Freiheit. Während der subjektive Geist nur die subjektive Freiheit als die Freiheit der Wahl von unmittelbar gegebenen Inhalten und Zwecken (der unmittelbare oder natürliche Wille) hat, eignet dem objektiven Geiste die formale Freiheit des persönlichen Willens (das Recht), die formale Freiheit des autonomen subjektiven Willens (die Moralität) und schließlich die substantiale Freiheit des substantialen Willens (die Sittlichkeit). Am Ende der Sittlichkeit aber bleibt noch die Unfreiheit übrig, welche der objektive Geist als solcher nicht überwinden kann. Die Freiheit ist auf der Stufe des objektiven Geistes immer noch begrenzt, denn sie erscheint in ihm als die Willensfreiheit. Die Freiheit als das Wesen des Geistes kommt zum Bewusstsein erst dann, wenn das Absolute als der absolute Geist in der Kunst, Religion und Philosophie bewusst wird. Jede von drei Gestalten des absoluten Geistes überwindet auf ihre Weise die Willensfreiheit, aber unter ihnen ist die Philosophie die freieste Gestalt des Geistes. In der Philosophie als der absoluten Wissenschaft wird die höchste Gestalt des Selbstbewusstseins des Geistes erreicht, bzw. die vollkommene Bewusstwerdung der Freiheit als seines Wesens. Dabei hat jede Stufe der Verwirklichung der Freiheit vom subjektiven über den objektiven zum absoluten Geist ihren notwendigen Ort und alle sind in das Ganze der notwendigen Momente des Systems vereinigt. Durch die Philosophie wird der Geist für seine Freiheit als sein Wesen vollkommen befreit. Er ist als das Zurückkehren zu sich selbst aus seinem Anderen bestimmt, so dass er schließlich alle Äußerlichkeit aufhebt, bzw. sie in seine Innerlichkeit aufnimmt, und dessen bewusst wird, dass das Andere von ihm nicht von ihm getrennt ist, sondern sein Anderssein ist. Vor aller Willensfreiheit, sei es Freiheit der Wahl, moralische Freiheit oder sittliche Freiheit, ist die Freiheit das Wesen des Geistes, und zwar die Selbstbestimmung, die keiner äußerlichen Bestimmung unterliegt: bei sich sein im Anderen seiner selbst, bzw. das Selbstverhältnis durch das Verhältnis zum Anderen als dem eigenen Anderen. Die Philosophie ist als die Wissenschaft des Absoluten zugleich die Wissenschaft der Freiheit. Durch die Freiheit kehrt sich das Absolute als die absolute Idee aus seinem An-sich-Sein frei in die Natur als in sein Anderssein um, kehrt im Geiste zu sich selbst zurück und offenbart sich in seiner Wahrheit als der absolute Geist. Die absolute Idee ist nichts anderes als der an sich seiende Geist, und das Absolute ist nach seiner höchsten Bestimmung der absolut selbstbewusste Geist. Die absolute Wissenschaft als die höchste Gestalt des absoluten Geistes ist das absolute Selbstbewusstsein des Absoluten selbst. Dass die Philosophie die Wissenschaft der Freiheit ist, bedeutet nicht nur, dass die Freiheit der 
Gegenstand der Philosophie ist, sondern auch, dass die Freiheit selbst durch die Philosophie in ihrer Wahrheit verwirklicht wird. Die Wahrheit der Freiheit ist, dass die Freiheit das Wesen des Absoluten ist. Das zu seiner Wahrheit befreite Absolute ist der absolute Geist.

\section{Schlüsselwörter}

Freiheit, das Absolute, absolute Idee, der absolute Geist, der objektive Geist, Freiheit des Willens, Geist, Philosophie als absolute Wissenschaft 